\title{
American Studies in Switzerland : A Preliminary Overview
}

\section{(2) OpenEdition}

\section{Journals}

Electronic version

URL: https://journals.openedition.org/ejas/1027

DOI: $10.4000 /$ ejas. 1027

ISSN: 1991-9336

Publisher

European Association for American Studies

Electronic reference

Martin Heusser, "American Studies in Switzerland : A Preliminary Overview", European journal of American studies [Online], 1-1 | 2006, document 19, Online since 16 January 2006, connection on 10 July 2021. URL: http://journals.openedition.org/ejas/1027 ; DOI: https://doi.org/10.4000/ejas.1027

This text was automatically generated on 10 July 2021 .

Creative Commons License 


\section{American Studies in Switzerland : A Preliminary Overview}

1 In contrast to many other Western European countries, there are no independent departments of American Studies at Swiss Universities. Many of the seminars and institutes are not large enough to allow narrow specialization. Chairholders are therefore often generalists in terms of teaching, although their research may be more focused. Some departments have professorships which are defined as chairs in "American Literature" (Basel, Geneva, Lausanne)-the majority, however, have chairs in "English and American Literature" (Bern, Basel, Fribourg, Neuchâtel, Zurich). It is therefore not possible to study "American Literature" or "American Studies" at one of the Swiss universities as a major, or, indeed, a first or second minor. Instead, American Literature / American Studies is integrated to a greater or lesser degree (depending on the students' interests and the offerings of the departments) in "English", "Anglistik", "English Languages and Literatures", etc. as the subjects are called in the various departments.

2 Historically, American Literature was offered for the first time in Switzerland at the universities of Basel and Zurich in the 1930s. In Basel, the first courses were taught by Prof. Henry Luedecke who later published a Geschichte der Amerikanischen Literatur (History of American Literature 1952, second edition 1963). In Zurich, American Literature was introduced to the department by Prof. Heinrich Straumann who also wrote a study of American Literature-American Literature in the Twentieth Century-an overview which was published in 1965 by Harper and Row. Both, Luedecke and Straumann basically taught English but offered courses in American Literature regularly.

3 In the course of the twentieth century, more and more universities filled at least one chair with a professor who would offer both, English and American Literature. The first (and up to now only) department to have a chair in American Studies was the University of Geneva where John G. Blair was Professor of American Literature and Civilization until recently.

4 At present, the situation of English and American Literature is the following (listed by university, in alphabetical order, and including also the chairs in linguistics which are part of many departments): 
Basel

Englisches Seminar

http://pages.unibas.ch/anglist/

- Prof. Dr. Balz Engler (English Literature)

- Prof. Dr. Hartwig Isernhagen (American Literature)

- Prof. Dr. Christoph Ribbat (Assistant Professor of North American Literatures and Cultures)

- Dr. Werner Brönnimann (Titularprofessor English and American Studies)

- Dr. Franziska Gygax (Titularprofessorin English and American Literature)

- Dr. Therese Steffen (Titularprofessorin Gender Studies in the Anglophone Context)

Bern

Institut für englische Sprachen und Literaturen

http://www.cx.unibe.ch/ens/

- Prof. Dr. Margaret Bridges (Medieval English Language and Literature)

- Prof. Dr. Werner Senn (English Literature)

- Prof. Dr. Gabriele Rippl (English and American Literature)

- Prof. Dr. Christiane Schlote (Assistant Professor in Post-Colonial Literature)

Fribourg

Department of English Studies

http://www.unifr.ch/das/

- Prof. Dr. Dimiter Daphinoff (English Literature)

- Prof. Dr. Anthony Mortimer (English Literature)

- Prof. Dr. Robert Rehder (English and American Literature)

Geneva

Département de langue et littérature anglaises

http://www.unige.ch/lettres/angle/

- Prof. Dr. David Spurr (Modern English Literature)

- Prof. Dr. Guillemette Bolens (Medieval English Literature)

- Prof. Dr. Deborah Madsen (American Literature)

- Prof. Dr. Lukas Erne (Modern English Literature)

Lausanne

English Department

http://www2.unil.ch/angl/

- Prof. Dr. Neil Forsythe (English Literature)

- Prof. Dr. Peter Halter (American Literature)

- Prof. Dr. Denis Renevey (Old and Middle English)

Neuchâtel

Institute of English Studies 


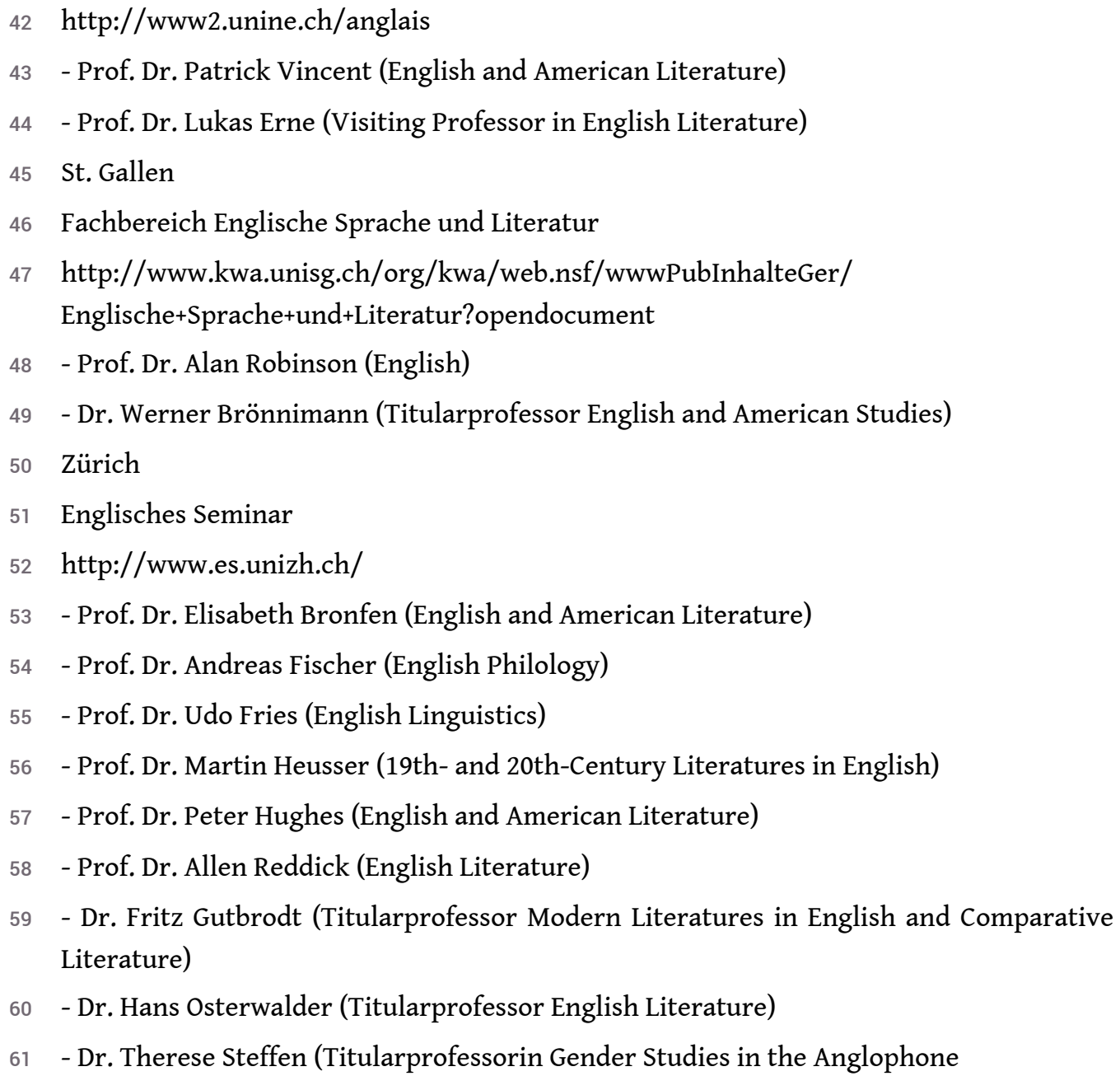

Keywords: American literature 